\title{
Jewish philosophy as a Direction of the World philosophy of Modern and Contemporary Times
}

\author{
I. Dvorkin \\ Hebrew University of Jerusalem \\ Mt. Scopus, Jerusalem, Israel, 9190501
}

\begin{abstract}
This article represents an analysis of the Jewish philosophy of the Modern and Contemporary as the holistic phenomenon. In contrast to antiquity and the Middle Ages, when philosophy was a rather marginal part of Jewish thought, in Modern Times Jewish philosophy is formed as a distinct part of the World philosophy. Despite the fact that representatives of Jewish philosophy wrote in different languages and actively participated in the different national schools of philosophy, their work has internal continuity and integrity.

The article formulates the following five criteria for belonging to Jewish philosophy: belonging to philosophy itself; reliance on Jewish sources; the addressee of Jewish philosophy is an educated European; intellectual continuity (representatives of the Jewish philosophy of Modern and Contemporary Periods support each other, argue with each other and protect each other from possible attacks from other schools); working with a set of specific topics, such as monism, ethics and ontology, the significance of behavior and practical life, politics, the problem of man, intelligence, language and hermeneutics of the text, Athens and Jerusalem, dialogism.

The article provides a list of the main authors who satisfy these criteria. The central ones can be considered Baruch (Benedict) Spinoza, Moshe Mendelssohn, Shlomo Maimon, German Cohen, Franz Rosenzweig, Josef Dov Soloveichik, Leo Strauss, Abraham Yehoshua Heshel, Eliezer Berkovich, Emil Fackenheim, Mordechai Kaplan, Emmanuel Levinas. The main conclusion of the article is that by the end of the 20th century Jewish philosophy, continuing both the traditions of classical European philosophy and Judaism, has become an important integral part of Western thought.
\end{abstract}

Key words: philosophy, Jewish philosophy, Jewish thought, intellectual continuity, philosophical direction, philosophical school

\section{Article history:}

The article was submitted on 14.05.2019

The article was accepted on 22.07.2019

For citation: Dvorkin I. Jewish Philosophy as a Direction of the World Philosophy of Modern and Contemporary Times. RUDN Journal of Philosophy. 2019; 23 (4):430 - 442. doi: 10.22363/23132302-2019-23-4-430-442

\section{Dvorkin I., 2019.}

(1) This work is licensed under a Creative Commons Attribution 4.0 International License https://creativecommons.org/licenses/by/4.0/ 


\section{Is there a Jewish philosophy of the Modern Times and Contemporary?}

When we talk about Antiquity and the Middle Ages, even the very existence of Jewish philosophy as a special intellectual phenomenon is highly controversial ${ }^{1}$. In Modern Time, the situation is radically changing. From the 17 th century to the present day, Jewish philosophy has been an undeniable fact.

This statement does not, of course, cast doubt on the existence, since ancient times, of a powerful and continuous tradition of Jewish thought. The intellectual virtues of wisdom, which is concentrated in Bible books, are universally recognized. But is this wisdom a philosophy? Quite often fragments from the Pentateuch, from the book of Job and the Psalms, the book of Ecclesiastes, and the book of Proverbs ${ }^{2}$ are included in philosophical anthologies. However, philosophy nevertheless differs from the literature of Wisdom in that it subjects its every position to free and strict criticism. Bible texts, of course, do not suggest this. True, if we consider the ancient Greek philosophy of the era of the pre-Socratics, then in it aphorism and imagery prevail over criticism. Nevertheless, in the subsequent period in philosophy, strict criteria were developed for the possibility of casting doubt on any position.

In the Hellenistic period, works appeared in Jewish intellectual literature that meet the above criteria, however, do they represent an integral direction? For example, the works of Philo of Alexandria, some apocryphal biblical books such as Maccabees, etc. Can we talk about intellectual continuity and connectedness?

In the Middle Ages, at least starting with Saadia Gaon, Jewish philosophy became a reality. Dozens of authors compose philosophical works in Jewish-Arabic and Hebrew. They argue with each other and with their Muslim and Christian colleagues, they rely on each other and argue with each other. However, even here the consideration of Jewish philosophy as an integral direction is very problematic!

When we talk about Modern Times, the situation is radically changing. The existence of Jewish philosophy of this era is obvious to readers and researchers. Nevertheless, its consideration here encounters a number of difficulties. Most of the works of Jewish philosophers are based on non-Jewish authors, addressed to a non-Jewish reader, written in European languages, moreover, in different languages, and belong to different philosophical schools.

For four centuries, from the beginning of the 17th century, Jewish thinkers of various planes created a huge number of texts. Some of them are not directly related to Jewish tradition, such as the works of K. Marx or Z. Freud. Even the writings of great

1 The issue of the existence and content of Jewish philosophy is considered in many studies, primarily in anthologies and in manuals on the history of Jewish philosophy (see bibliography). In addition, there are also special studies on this topic. In this work, we rely on the article by Ilya Dvorkin "Between Prophecy and Pure Reason: How is Jewish Philosophy Possible?". In: JUDAICA PETROPOLITANA. № 3 (2014). P. 10-33.

2 Most reviews of Jewish philosophy begin with the biblical period. See: [1. P. 15-42; 2. P. $12-$ $24 ; 5$, P. 13-37]. 
philosophers, Jews of origin, such as E. Husserl, A. Bergson or L. Wittgenstein cannot be considered "Jewish philosophy". The same can be said of such thinkers as L. Shestov and S.L. Frank. On the other hand, throughout this era there is a powerful intellectual tradition of rabbinical literature. It relies heavily on Jewish and non-Jewish philosophy from different times. These include the mystical literature of Kabbalah and Hasidism, the Jewish traditional ethics of Musar, the Jewish exegesis of the Modern Times, often referring to philosophical motives. To all this, significant socio-political literature on topical issues of the life of Jewish communities, anti-Semitism, etc. should be added. In many cases, in all this variety of literature it is very difficult to draw a line and distinguish philosophy itself. Perhaps this is Jewish thought, but not Jewish philosophy.

For all these reasons, in order to talk about the Jewish philosophy of the Modern Times, it is necessary to define clear criteria for what we attribute to it and what not. However, before formulating these criteria, we intuitively define the circle of authors who constitute the direction of the philosophy of the Modern and Contemporary Times, which is most likely to be called Jewish philosophy.

\section{What does the Jewish philosophy of the Modern and Contemporary Times include, and what is its continuity?}

Although the process of philosophical creativity in the Jewish tradition did not stop throughout the Middle Ages and continued during the Renaissance, the history of the Jewish philosophy of the Modern Time can begin with the grandiose figure of Baruch (Benedict) Spinoza $(1632-77)^{3}$.

The point is not only that Spinoza's predecessors in Italy, Moravia, Poland and the Land of Israel do not meet our criteria for Jewish philosophy. For example, the Dialogues on Love, written in Italian by Yehuda Abrabanel, undoubtedly belong to the masterpieces of Renaissance philosophy. The same can be said of a number of other works written by other Jewish thinkers in Italy. However, when we talk about the philosophy of the New Time, we mean a certain continuity of texts and ideas from which the philosophy of the Renaissance, including the Jewish one, is somewhat knocked out. A similar situation is observed with the outstanding philosopher of the 17th century, Isaac Cardozo (1603/4 - 1683), who wrote a number of important works in Spanish and Latin. However, these works did not receive a substantial reception in the subsequent philosophy, both Jewish and world. Other examples include texts written in Hebrew by Maaral from Prague and Rabbi Moshe Chaim Lutzato (Ramhal). They had a great influence on the development of rabbinical literature, but did not become part of Jewish philosophy. The choice of Spinoza as the starting point of a new Jewish philosophy is due to the fact that Spinoza generally began a new era in philosophy. The first half of the 17 th century

3 The question of whether Spinoza can be considered as a Jewish philosopher has been widely debated for over a hundred years. Recent works on this topic show that insufficient consideration of his connection with Maimonides, Kreskas and other authors leads to a significant misunderstanding of his philosophy. See: Steven Nadler (ed.), Spinoza and Medieval Jewish Philosophy, Cambridge University Press, 2014. 
is the time when the creators of the European philosophy of the Modern Time - Francis Bacon, Rene Descartes, Thomas Hobbes lived. Spinoza also belongs to this list. At the same time, the philosophy of Spinoza is the starting point of the Jewish philosophy of the Modern and Contemporary Times. Mendelssohn, Maimon, Cohen, Rosenzweig, Levinas and many others continue and argue with it.

Another key figure in the formation of Jewish philosophy of the Modern and Contemporary Times was Moshe Mendelssohn (1729-86). His role in the formation of Jewish philosophy is significantly different from the role of Spinoza. If Spinoza was the subject of ongoing controversy, then Mendelssohn, on the contrary, was its important foundation. He first showed that a combination of Jewish philosophy with European is possible. Mendelssohn enjoyed universal respect, both among representatives of the Jewish community and among the educated sections of German society. Being one of the central figures of 18th century German philosophy, he formed the starting point for subsequent Jewish philosophy.

The life and work of another great representative of the Jewish philosophy of this era, Shlomo Maimon (1761-1800), developed quite differently. His real name is Shlomo bin Yehoshua Hyman. The name Maimon was chosen, of course, not by chance. An enthusiastic follower of Maimonides, he was no less Kantian and Leibnizian. As a representative of the new philosophy, S. Maimon was far ahead of his time. His ideas continued to be popular in both Jewish and non-Jewish philosophy to this day. Among the Jewish philosophers of the New Age there are rebels and subversors of tradition such as Spinoza and Maimon and its defenders like Mendelssohn. Another example of this kind is Rabbi Nachman Krokhmal (1785-1840), who, as the rabbi of the city of Zholkov, became a major philosopher who formed his own original teaching.

Of the Jewish thinkers of the first half of the 19th century, several significant figures can be named, which proves that this philosophical trend in the 19th century became a reality. Among them are Shlomo Steinheim (1789-1866), Shlomo Formshteher (1808-1889), Samson Rafael Hirsch (1808-88), Moshe Hess (1812-75), Moritz Lazarus (1824 - 1903), Manuel Yoel (1826 - 90). The latter also played an important role in the study of the connection of the Jewish philosophers of the Modern with the philosophy of the Middle Ages, which contributed to the awareness of the significance of the very phenomenon of the new Jewish philosophy.

Now we can move on to the most significant phenomenon in the Jewish philosophy of the Modern and Contemporary Times to the doctrine of Hermann Cohen (18421918). Being the most important point of convergence and divergence of Jewish thought of the Middle Ages, New Time and the 20th century, Cohen was also the largest European philosopher, the significance of which is becoming increasingly apparent to modern scholars. Most Jewish philosophers of the 20th century are either direct followers of Cohen, or largely inherit his ideas.

Among the students and followers of Cohen there are many prominent scientists and philosophers, including those who were engaged in Jewish thought, but Franz Rosenzweig (1886-1929) was the most famous successor of Cohen in the field of Jewish philosophy. 
If Cohen, like his predecessors, is represented by two distinct, albeit related, images of the German and Jewish philosophers, then in Rosenzweig these images cannot be separated from each other. For this reason, European Jewish philosophy can be counted from it as an integral phenomenon. Something similar can be said about another follower of Cohen - the Nevel thinker, Bakhtin's friend Matvey Kagan (1888/9-1837). In his philosophical passages published in $2004^{4}$, he appears simultaneously as a Russian, German, and Jewish thinker. Rosenzweig's closest friend and partner in many endeavors Martin Buber (1878 - 1965) became a completely dissimilar and even largely opposite figure in the development of Jewish and world philosophy. However, in him Jewry and Jewish thought become an integral part of its philosophical heritage.

Most Jewish philosophers, whose thinking was formed in the interwar period, are somehow connected with the legacy of H. Cohen. Some of them are like Jacob Gordin (1896-1947) and Rabbi Y.D. Soloveichik (1903-1993) wrote their dissertation works on Cohen and relied on him in their own philosophical constructions, others, like L. Strauss (1899-1871), G. Scholem (1897-1982), argued with Cohen. The line of Cohen, Rosenzweig and Buber is also continued by A.Y. Heschel (19071972), E. Berkovich (1908-1992) and J. Agus (1911-1986), E. Fackenheim (19162003). These authors are characterized by a reference to the heritage of Maimonides, interaction with the teachings of Spinoza, reliance on the ideas of Buber and Rosenzweig. The main thing is that for all these authors, Jewish thought and European philosophy are inseparable unit. The founder of the concept of Jewish civilization M. Kaplan (1881-1984) worked on the same basis. It is important to note that all of these authors and many other thinkers of this era easily combine appeal to European or American sources with reliance on Jewish philosophy and classical Jewish texts. To complete our short list, it is necessary to dwell on the last great Jewish philosopher of the 20th century E. Levinas (1906-1995). Belonging in many respects to the school of alternative neo-Kantianism - phenomenology, Levinas was nevertheless involved in a circle of ideas that was very close to all the authors listed. Being a pupil of J. Gordin and a follower of F. Rosenzweig, Levinas develops ideas in many respects close to Cohen, although by his method he dissociates himself from Cohen in every way. However, he affirms the most important principle of Cohen's philosophy, the priority of ethics over metaphysics ${ }^{5}$. Moreover, if Kohen relies on Kant and the biblical text, then Levinas on Husserl and the Talmud.

To summarize some of our review. The main conclusion that we can draw is that towards the end of the 20th century a direction has formed in world philosophy, which can be called Jewish philosophy. Despite the difference in methods and approaches, despite the use of different languages and living in different countries, this direction can be considered as a whole that has a chance of significant development in our time.

${ }^{4}$ See: Kagan M.I. On the course of history. (In Russian: O hode istorii). Moscow, Yazyki slavyanskikh kultur, 2004.

${ }^{5}$ Unlike Cohen, for whom systematic philosophy and Jewish religious philosophy are clearly divided and have a different orientation, for Levinas, as before for Rosenzweig, religious thought, Judaism and classical philosophy are not separable at all. Thus, Levinas belongs to a new era of Jewish philosophy, when it becomes an integral part of the global intellectual tradition. 


\section{How the Jewish philosophy of the Modern and Contemporary Times is determined}

Now that we have shown the development of Jewish philosophy as a special direction of Western philosophy of the Modern and Contemporary times, it is necessary to formulate criteria that allow us to define this phenomenon more accurately. Of course, it would be logical to start with these criteria, and then list the philosophers who satisfy them. But for convenience of presentation, we used the reverse order. Meanwhile, we implicitly used the five most important criteria for belonging to Jewish philosophy, namely: belonging to philosophy in general, reliance on Jewish sources, appeal to an educated European reader, including a Jewish reader, intellectual continuity and consideration of specific topics specific to this direction. It is clear, that these criteria are not as strict as, for example, using a specific research method or belonging to a particular school. It is impossible to consider Jewish philosophy within, for example, phenomenology or neo-Kantianism. But the same is true of other national philosophical traditions, such as, for example, classical German philosophy or Russian philosophy.

Consider all these criteria in more detail.

\subsection{Belonging to philosophy itself}

When we talk about Jewish philosophy, we consider philosophy in the generally accepted sense, i.e. not social and social literature, not wisdom and thoughts about life, not theology or biblical comments. Philosophy deals with the study of general worldview issues using certain logical and critical methods. Along with theoretical issues related to ontology, the theory of knowledge, the nature of God and man, the laws of the existence of the world, philosophy also considers practical issues, such as ethical principles and forms of relations between people, questions of state structure and political problems, historical conflicts. The relationship between theoretical and practical philosophy is especially important for Jewish philosophy, in which the problems of the existence of Jewry are considered from fundamental theoretical points of view.

\subsection{Reliance on Jewish sources}

All the authors whom we consider in the context of the Jewish philosophy of the Modern and Contemporary times possessed, so to speak, dual intellectual citizenship. All of them were undoubted experts on the European or more broadly Western intellectual tradition, belonged to it and were its bright representatives. But all of them, at the same time, were deeply connected with the Jewish tradition of past centuries. Knowledge of Hebrew, classical Jewish literature, familiarity with its problems and achievements is an undoubted unifying beginning for this direction. The presence of a serious Jewish education and reliance on medieval Jewish philosophy is for us an important criterion that a particular philosopher belongs to this philosophy.

An example is the attitude to biblical sources. Almost all Jewish philosophers of the Modern and Contemporary Times consider the Torah, the Prophets and the Scriptures in the context of the medieval Jewish commentatorial tradition. Some acknowledge the deepest philosophical ideas in biblical texts, others deny them, but everyone views them as a source. 
Another example is the philosophy of the central author of the Jewish Middle Ages, Maimonides. Attitude to Maimonides is an important point for most of the authors we are considering. Some argue with Maimonides, others admire him and try to imitate him. Maimonides interpretations are different for everyone, but the fact of the relationship is not in doubt. Thus, two Jewish philosophers of the 20th century Herman Cohen and Emmanuel Levinas turn significantly to the ideas of Maimonides, and despite that their understanding of Maimonides has little in common, the very support of his philosophy forms a common basis.

The designated criterion poses serious problems for the researcher, and for the reader. The fact is that all the authors we are talking about, along with Jewish sources, use well-known world sources, especially ancient Greek philosophy and contemporary European philosophy. Moreover, as a rule, they appeal to a wide circle of readers, often not particularly educated in Jewish studies. Therefore, they try to write in a common language and their Jewish sources are very implicit. This problem, in our opinion, is not solvable without considering the Jewish philosophy of this period as a whole and correlating it with predecessors belonging to different traditions. For readers, if they want to really understand something, it is necessary to familiarize themselves with the sources of this author and this text; for researchers, a detailed analysis of the entire communication system is necessary.

\subsection{Addressee}

In relation to its addressee, the Jewish philosophy of the New and Modern times is significantly different both from medieval Jewish philosophy and from the rabbinical scholarly literature of the Time. Although Jews remain an important addressee of philosophical teachings and texts, an educated European becomes their main reader. In this, Jewish philosophy differs little from other areas of European philosophy. It is clear that Kant refers not only to the Germans, but Rousseau not only to the French. However, nevertheless, its national reader remains a significant addressee, again, as in other areas. It is clear that Vladimir Solovyov is aware that his works will be read, first of all, by native speakers of the Russian language and Russian culture, which does not negate their universal significance.

In the Jewish philosophy of the Modern Age, this feature is perhaps more complex and non-trivial in nature than other philosophies. On the one hand, the main addressee of the Jewish philosophical texts of this era is an educated European, even more so than Russian, German, French or Italian. The fact is that Jewish philosophy of this time partly opposes the more particularistic approach of rabbinical literature, which also continues the tradition of medieval Jewish philosophy. It is addressed primarily to Jews and is primarily concerned with Jewish affairs. Although it often touches on important and universal human problems, it is characterized by its appeal to an exclusively Jewish reader. Given that Jewish philosophy is often formed in the same environment, its authors emphasize its universal character and universal significance. This makes Jewish philosophy even more universalistic than its neighboring European one. It is also worth noting that the Jewish reader of Jewish New Age philosophy is usually an educated European 
who speaks many languages and combines Jewish culture with European. This reader lives in different countries and communicates with representatives of different cultures and religious denominations. He can live in Russia, America, Germany or the United States, and maybe in Palestine, Israel, or in Asia.

This circumstance gives rise to two important features of Jewish philosophy of this period. First, she must speak a language that is understandable to her reader. Therefore, for example, Spinoza, Mendelssohn or Maimon, despite the fact that they rely on medieval Jewish philosophy and rabbinical literature, cannot assume such knowledge from their non-Jewish readers and the entire Jewish layer of their philosophy remains largely an element hidden from the reader. Secondly, no matter how universal the content of this philosophy is, the European non-Jewish reader always remembers that the author of the essay is a Jew educated in Judaism. Therefore, for example, Hegel claims that Spinoza's monism is of Jewish origin. And Hegel is right in this, but he does not have the tools to value his own statement. When Leibniz ascribes Spinoza to Kabbalists, he, of course, proceeds from his Jewishness and knowledge of the Kabbalistic tradition, but for Leibniz himself this tradition is rather vague. As you know, Deleuze begins his book about Spinoza with the following words: "Let me ask you, what made you read Spinoza? Is it not that he is a Jew? No, Your Honor. I did not know at all who he was and what he was doing..." ${ }^{.6}$. Such an attitude to the representatives of the Jewish philosophy of the New Time is almost inevitable, because they seem to be two realities at once. For example, the philosophy of Cohen or Levinas can be perceived as universally arbitrary, but usually no one forgets that the authors of these universalist teachings are Jewish thinkers.

At the same time, it is necessary to say a few words about the Jewish readers of the Jewish philosophy of the New Time. For them, the authors of this philosophy represent an object of a certain personal intimacy and at the same time often an aggravated confrontation precisely from Jewish positions. Does Mendelssohn adequately present the ideas of Judaism to European readers, is Levinas really a connoisseur of the Talmud, whom he comments on? Questions of this kind are most likely characteristic of Jewish readers of these texts.

\subsection{Intellectual continuity}

The unity of sources is itself a form of intellectual continuity. However, along with this, the representatives of the Jewish philosophy of the New and Modern Times lean on each other, argue with each other and protect each other from possible attacks from other schools. Thus, the entire Jewish philosophy of the New and Modern Times is a single, internally connected whole. One or another author may be less included in this whole, but the continuity of the direction itself is preserved.

One of the important points uniting the Jewish philosophy of this period is its relation to Spinoza. Almost all the authors whom we are considering react quite sharply to it. Mendelssohn argues with Spinoza and defends his friend Lessing from the charges

${ }^{6}$ See: Deleuze, Gilles. Spinoza: Philosophie pratique. P.: PUF, 1981. 
of Spinozism. At the same time, he accepts some of Spinoza's principles and in many respects continues his problems. Shlomo Maimon defends Spinoza from accusations of atheism and materialism. Hermann Cohen, Franz Rosenzweig and Emmanuel Levinas in their works try to overcome Spinoza. Leo Strauss devoted his main works to Spinoza and, to a large extent, derives his political philosophy from it. Even the concept of the Jewish civilization of Mordecai Kaplan is not built without the influence of Spinoza. Although Spinoza is by no means the creator of the Jewish philosophy of the New Time, his ideas, including through their refutation, became an important stimulus for her.

A similar role, although in a completely different way, was played in the formation of the new Jewish philosophy by the ideas of Moshe Mendelssohn. Mendelssohn was not such a significant figure in world philosophy as Spinoza, but he influenced Jewish thought very strongly. As a major European philosopher and, at the same time, a respected member of the Jewish community of Berlin, he showed that Jewish thought can integrate perfectly into European philosophy. In his footsteps were Krochmal, Cohen, Rosenzweig, Levinas and many others. Mendelssohn picked up the topic of the relationship between the Jewish state and the universal state based on the principles of reason, initiated by Spinoza, as well as the problem of the relationship between the state and religion. These topics become relevant to all subsequent Jewish philosophy. It is equally important that Mendelssohn tried to give an interpretation of universal philosophical questions based on the concept of ethical monotheism, i.e. ideas about Judaism as a kind of philosophy. From these positions, Mendelssohn examined the questions of the unity and transcendence of God, the immortality of the human soul, the connection of ethics and metaphysics. All these topics will become important and characteristic for subsequent Jewish philosophy.

Cohen's philosophy has a direct connection with the ideas of Spinoza and Mendelssohn and has much in common with the ideas of Maimon. For example, like Maimon, although independently of him, Cohen introduces the concept of differential into the consideration of the problem of things in himself. At the same time, Cohen himself is the most important crossroads on the path to the formation of Jewish philosophy of the 20th century. Rosenzweig speaks of himself as a disciple and successor to Cohen. Buber is opposed to Cohen, but in many ways develops his ideas. Leo Strauss also confronts Cohen. Soloveichik and Gordin write their dissertations on Cohen and subsequently rely on his philosophy in their teachings. Levinas belongs to a different philosophical direction, i.e. to phenomenology, and not neo-Kantianism, but he has a common position with Cohen on important issues, for example, the priority of ethics in relation to ontology, etc. The connection between the teachings of Levinas and Cohen is carried out, including through other representatives of Jewish philosophy.

Speaking about the coherence and continuity of modern Jewish philosophy, we certainly should not forget that it is all part of another whole, namely the Western philosophy of the New and Modern Times. Leibniz relies on Spinoza, Fichte and Hegel on Maimon, Deleuze - on both of them, Natorp and Cassirer - on Cohen, etc. However, such connections are completely natural for any other national traditions in the philosophy of the New Time. 


\subsection{Addressing a set of specific topics}

Let us formulate a short list of the most important topics that are characteristic of the Jewish philosophy of the New and Modern times. A more detailed list of topics will be presented in articles and notes regarding specific philosophers.

Monism. The problem of the unity of God, the universe, human nature clearly worries Jewish philosophers. Spinoza contrasts his monism with Descartes' dualism. Maimon removes the problem of things in himself and moves away from Kant's dualism. Krochmal considers Jewish history based on the idea of a unified history of the human race. Herman Cohen gives a new interpretation of the unity of God, speaking of uniqueness. The issue of unity remains at the center of attention of all Jewish philosophers of the 20th century, although their interpretation is significantly different.

Ethics and ontology. The tradition of comparing ethics with metaphysics comes to Jewish philosophy from Maimonides. The connection of ethics with ontology is the central theme of Spinoza's Ethics. In the philosophical teachings of Cohen, Rosenzweig, Buber, Levinas, ethics are largely opposed to ontology, but the significance of this relationship is preserved.

Significance of behavior and practical life. The importance of practical life and human behavior in the material world, as well as the role of ethics, follows from the philosophy of Maimonides. For him, the main theme of philosophy is the path of man to God. He perceives the same philosophical task from Maimonides and Spinoza. Jewish philosophy, unlike Christian, is less characterized by opposition of material and spiritual. From the beginning corporeality and everyday life are important for it. For this reason, the problems of laws and customs of behavior are present in the teachings of Spinoza, Mendelssohn, Cohen, Rosenzweig and others. Soloveitchik creates a kind of halacha philosophy, i.e. structure of behavior. Kaplan puts everyday behavior at the center of his civilizational approach.

Politics. Almost all Jewish philosophy of the Modern and Contemporary times contains political philosophy as one of the most important components. Spinoza writes the Theological and Political Treatise and The Political Treatise. Mendelssohn creates "Jerusalem". Krochmal, in the framework of his historical conception, formulates his conception of a nation. The theory of the state is one of the most important elements of Cohen's ethics. The third part of the "Star of deliverance" Rosenzweig turned against tyrants, is a kind of concept of community and power. Leo Strauss creates political philosophy as a special discipline. Formulated in Spinoza's Ethics, the problem of freedom is continued in Levinas's philosophy.

The problem of man. It is clear, that the theme of man is central in general to the philosophy of the Modern Time. But in Jewish philosophy, this theme has its own particular nuances. For most Jewish philosophers, man appears as a problem. Already in Spinoza's writing, the human soul finds itself in complex, problematic relationships with God and the world. Mendelssohn considers man in interaction with God and the world, as well Maimon after him. Cohen builds his specific anthropology, speaking of the Mitmensch. A person in him combines an individual, personal and social character. Rosenzweig considers man as one of the elements of his "Star of Deliverance", comparing 
it with God and the world. Buber also puts the "human problem" at the center of his philosophy. An interesting interpretation of man in connection with the Holocaust is found in the philosophy of Fackenheim.

Intelligence, language and hermeneutics of the text. The problem of hermeneutics and language comes to the Jewish philosophy of Modern Time also from Maimonides. In his teaching, one of the central roles is played by the so-called "language of the sons of men", which is built on the basis of metaphor and imagery. If Spinoza in defiance of Maimonides develops his hermeneutics of the biblical text, depriving it of its conceptual content, then Mendelssohn tries to revive Maimonides's approach and speaks of the iconic structures realized in religion. Shlomo Maimon also talks about signs and language. They play an important role in the teachings of Soloveitchik. Picking up this theme, Cohen in his works develops a whole system of interpretation of biblical texts. And Rosenzweig declared "grammar" as the most important organon, which is responsible for the description of the processes occurring in the present.

Athens and Jerusalem. Attempts to contrast the Greek and Jewish views of the world were carried out already in antiquity. You can recall Tertullian, and Augustine, and the midrash Eicha Rabba. But in the philosophy of Modern Time, this topic was started by Moshe Mendelssohn, who, having written his treatise "Jerusalem", began a new process of interrelation. Although Cohen does not directly deal with the opposition of the Greek and Jewish value systems, the comparison of Greek philosophers and Jewish prophets is typical for him. A direct juxtaposition of Jerusalem and Athens is given in his philosophy by Leo Strauss. This theme is familiar to Rosenzweig and Levinas.

Dialogism. The philosophy of dialogue was formed already in the 20th century and representatives of Jewish philosophy accepted in this process. At its source is the mighty figure of Herman Cohen. Among the creators of the philosophy of dialogue, the role of Rosenzweig and Buber is very significant. The importance of Jewish philosophers in shaping a philosophy of dialogue does not seem to be accidental. Since the times of the Tanakh and Talmud, dialogism has been an extremely important component of Jewish thought.

\section{Reception of Jewish philosophy of the Modern and Contemporary Times and its prospects}

Understanding the history of Jewish philosophy comprises in three main sources. First, it, like any philosophy, is engaged in the study of itself. For the most part, each subsequent author carries out a critical analysis of the ideas of his predecessors. Thus, the philosophy of Spinoza is considered in detail among Jewish and non-Jewish philosophers of the 18-20 centuries. Similarly, philosophies of other authors are considered.

Along with this, there are many anthologies and textbooks that try to consider the history of Jewish philosophy as a special phenomenon. Books of this kind differ significantly in content and general concept. So, the famous "Philosophy of Judaism" by Y. Gutman does not imply the existence of Jewish philosophy as a philosophy, but traces the history of Jewish religious thought". The book of J. Eigus, "Modern philo-

\footnotetext{
See: [2].
} 
sophical trends in Judaism"8 analyzes Jewish thought as a whole and explores its evolution. The works of Bergman, Rotenstreich and Schweid are trying to identify the main thematic block of Jewish philosophy. The History of Jewish Philosophy, published in 1997 as part of the Routledge series on world philosophy, is a collective monograph that examines separately the different stages of Jewish thought ${ }^{9}$. Recently published in the US, the book "New Directions in Jewish Philosophy"10 focuses on current issues and peculiar solutions in the field of Jewish philosophy.

Finally, there are many works devoted to individual thinkers, considering them both historically and purely in philosophical terms. In this direction, great successes have been achieved in recent years.

If we compare the state of Jewish philosophy in antiquity, the Middle Ages and in our time, we see a very significant difference. In the past, her main occupation was reconciling biblical revelation with critical reason. This situation turns philosophy into a fundamentally secondary phenomenon of intellectual life. However, the efforts of the Jewish philosophers of Modern and Contemporary Time have made it clear that Jewish thought is not only reconciliation with reason, but reason itself. In the 20th century, Jewish philosophy advanced to the forefront in world philosophy. It answers the exciting questions of not only Jewish, but also world culture, it is addressed not only to the Jewish tradition, but to all thinking people.

This circumstance encourages us and allows us to think that a great future belongs to Jewish philosophy. We hope that this anthology will contribute to this, because many of its readers can join the process of popularization and development of Jewish philosophy.

\section{References}

נימרק, דוד, תולדות הפילוסופיה בישראל: על פי סדר המחקרים. מאת דוד בן שלמה נימרק. ניו יורק; ווארשה;

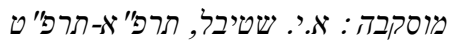

[2] Guttmann J. Die Philosophie des Judentums. München: E. Reinhardt, 1933.

[3] Agus J. London-New-York, 1959.

[4] Wolfson HA. Studies in the history of philosophy and religion. Cambridge: Harvard University Press, 1973 - 1977.

[5] History of Jewish philosophy. (Routledge history of world philosophies 2). Daniel H. Frank Oliver Leaman (Hg.). London; 1997.

[6] Hayoun Maurice-Ruben. Geschichte der jüdischen Philosophie. WBG: Darmstadt; 2004.

[7] The Cambridge History of Jewish Philosophy. Volume 1. Steven Nadler and T.M. Rudavsky; Cambridge University Press, 2008.

[8] Shatz D. Jewish thought in dialogue: essays on thinkers, theologies, and moral theories. Brighton, MA: Academic Studies Press; 2009.

[9] New Directions in Jewish Philosophy. Paperback. Aaron W. Hughes (Editor), Elliot R. Wolfson (Editor). Indiana University Press; 2009.

[10] Schweid E. A history of modern Jewish religious philosophy by Eliezer Schweid. Translation by Leonard Levin. Leiden; Boston: Brill; 2011.

\footnotetext{
8 See: [3].

${ }^{9}$ See: [5].

${ }^{10}$ See: [9].
} 


\title{
Еврейская философия как направление мировой философии нового и новейшего времени
}

\author{
И. Дворкин \\ Еврейский университет в Иерусалиме \\ Иерусалим, Израиль, 9190501
}

Настоящая статья представляет собой анализ еврейской философии Нового и Новейшего Времени как целостного явления. В отличии от древности и средневековья, когда философия представляла собой довольно маргинальную часть еврейской мысли, в Новое Время формируется еврейская философия как особое направление мировой. Несмотря на то, что представители этого направления писали на разных языках и активно участвовали в деятельности разных национальных школ философии, их творчество имеет внутреннюю преемственность и целостность.

В статье формулируется следующие пять критериев принадлежности к еврейской философии: принадлежность собственно к философии; опора на еврейские источники; адресатом еврейской философии является образованный европеец; интеллектуальная преемственность (представители еврейской философии Нового и Новейшего Времени опираются друг на друга, спорят друг с другом и защищают друг друга от возможных нападок со стороны других школ); обращение к набору характерных тем, таких как монизм, этика и онтология, значимость поведения и практической жизни, политика, проблема человека, интеллект, язык и герменевтика текста, Афины и Иерусалим, диалогизм.

В статье приводится перечень основных авторов, удовлетворяющих этим критериям. Центральными из них можно считать Баруха (Бенедикта) Спинозу, Моше Мендельсона, Шломо Маймона, Германа Когена, Франца Розенцвейга, Йосефа Дова Соловейчика, Лео Штрауса, Авраама Иегошуа Хешеля, Элиезера Берковича, Эмиля Факенхейма, Мордехая Каплана, Эммануэля Левинаса. Основной вывод статьи: к концу 20-го века еврейская философия, продолжая как традиции классической европейской философии, так и иудаизма, стала важной неотъемлемой частью западной мысли.

Ключевые слова: философия, еврейская философия, еврейская мысль, интеллектуальная преемственность, философское направление, философская школа

\section{История статьи:}

Статья поступила 14.05.2019

Статья принята к публикации 22.07.2019

Для цитирования: Dvorkin I. Jewish Philosophy as a Direction of the World Philosophy of Modern and Contemporary Times // Вестник Российского университета дружбы народов. Серия: Философия. 2019. Т. 23. No 4. С. 430 - 442. doi: 10.22363/2313-2302-2019-23-4-430-442

\section{Сведения об авторе:}

Илья Дворкин — профессор Еврейского университета в Иерусалиме (e-mail: idvorkin@mail.ru). 